\title{
Rural development and family agriculture in the Brazilian state of Minas Gerais in the light of multivariate data analysis
}

\author{
Desenvolvimento rural e agricultura familiar em Minas Gerais à luz da análise \\ multivariada de dados
Dévéloppement Rurale et Agriculture Familiale dans l'état brésilien de Minas Gerais à la lumière de l'analyse de données multivariées

\section{Desarrollo rural y agricultura familiar en el estado brasileño de Minas Gerais a la luz del análisis multivariado de datos}

\author{
Luana Ferreira dos Santos ${ }^{1}$ \\ Marco Aurélio Marques Ferreira ${ }^{2}$ \\ Ana Paula Teixeira de Campos ${ }^{2}$ \\ Recebido em 17/01/2018; revisado e aprovado em 25/03/2018; aceito em 23/04/2018 \\ DOI: http://dx.doi.org/10.20435/inter.v19i4.1817
}

\begin{abstract}
This paper analyze the rural development in the Brazilian state of Minas Gerais and verify if family farming is a key factor in explaining it. The factor analysis reinforce the importance of the six aspects that influence rural development. The Rural Development Index show that most of the municipalities falls within the category of medium rural development followed by the categories high and low development. The multinomial logit model showed of $45.6 \%$ of municipalities, family farming is able to predict the level of rural development.
\end{abstract}

Keywords: rural development; family agriculture; multivariate data analysis; Minas Gerais; Brazil.

Resumo: Este artigo analisa o desenvolvimento rural no estado de Minas Gerais e verifica se a agricultura familiar contribuiu para explicá-lo. A análise fatorial reforça a importância de seis aspectos que influenciam o desenvolvimento rural. O Índice de Desenvolvimento Rural mostra que a maioria dos municípios são classificados na categoria de médio desenvolvimento rural, seguido pelas categorias de alto e baixo desenvolvimento. O modelo logit mostrou que em 45,6\% dos municípios a agricultura familiar é capaz de prever o nível de desenvolvimento rural.

Palavras-chave: desenvolvimento rural; agricultura familiar; análise multivariada de dados; Minas Gerais.

Résumé: Cet article analyse le développement rural dans l'état brésilien de Minas Gerais et vérifie si l'agriculture familiale est un facteur clé pour l'expliquer. L'analyse factorielle renforce l'importance de six aspects. l'indice de développement rural montre que la plupart des municipalités se sont classées dans la catégorie du développement rural moyen, suivies des catégores de développement haute et basse. Le modèle logit a montré que dans 45,6\% des communes, l'agriculture familiale est capable d'prévoir le niveau de développement rural.

Mots-clés: dévéloppement rurale; agriculture familiale; l'analyse de données multivariées, Minas Gerais, Brésil.

Resumen: Este artículo analiza el desarrollo rural en el estado de Minas Gerais y verifica si la agricultura familiar ha contribuido a explicarlo. El análisis factorial refuerza la importancia de seis aspectos que influencian el desarrollo rural. El índice de desarrollo rural muestra que la mayoría de los municipios son clasificados en la categoría de medio desarrollo rural, seguidos por las categorías de alto y bajo desarrollo. El modelo logit demostró que en el 45,6\% de los municipios la agricultura familiar es capaz de predecir el nivel de desarrollo rural.

Palabras clave: desarrollo rural; agricultura familiar; análisis multivariado de datos; Minas Gerais; Brasil.

\footnotetext{
${ }^{1}$ Universidade Federal do Rio Grande do Norte (UFRN), Nata, Rio Grande do Norte, Brasil.

${ }^{2}$ Universidade Federal de Viçosa (UFV), Viçosa, Minas Gerais, Brasil.
} 


\section{INTRODUCTION}

The trajectory of the conceptual discussions about the rural development advances under external influences and according to the historical context of a certain region or country. In this sense, different studies address the main discussions triggered by the processes of development of rural spaces in the international scenario (DELGADO, 2001; NAVARRO, 2001; ELLIS; BIGGS, 2001; SCHNEIDER, 2010; GRISA; SCHNEIDER, 2015).

Ellis and Biggs (2001) performed a retrospective of the main changes in the thoughts on rural development from 1950 to 2000 in developed countries. According the authors, this sequence of ideas includes the modernization of agricultural activities in the 1950s and 1960s, the State intervention in the 1970s, the liberalization of markets in the 1980 s and the approaches on participation and empowerment of rural inhabitants that still prevail in the discussions related to the rural environment. From these approaches, themes that deal with poverty alleviation (1980), poverty reduction (1990) and eradication of poverty (2000) are recurrent and have increasing importance, and may therefore be the ones that really express crucial issues related to rural environment.

As well as in developed countries, in Brazil, the agricultural modernization was also one of the first discussions related to the development of rural areas, succeeded by discussions on the agrarian structure. According to Delgado (2001), in the 1960s, the economic reflection on the rural sector was organized around land reform, accentuating the debate on agrarian problems such as land tenure and other issues such as supply and demand of agricultural products, foreign trade and employment. Between 1985 - 1965, Delgado (2001) reports on the stage of "conservative modernization" in which agriculture was modernized but didn't face any change in its land structure. Since a highly concentrated profile was maintained with regard to land ownership and support to the large landholdings.

According to the author, this period was born with the defeat of the movement for land reform and it was considered the "golden age" of the development of capitalist agriculture in integration with the urban and industrial economy and with the external sector under the strong financial mediation of the public sector. In addition, there is an adoption scenario of technological packages of the "green revolution" which consisted of the mechanization of agriculture, the use of chemical fertilizers, agrochemicals, the purchase of seeds and seedlings developed by research companies, known as modernity.

Navarro (2001) despite the dominance of agricultural modernization model, this process has not benefited equally all segments of Brazilian farmers, contributing to the increase of social inequality in the field. Thus, in the 1970s the focus of agricultural development waned and a set of programs was implemented by the military in the poorest regions (Northeast, in particular), under the aegis of rural development. However, Navarro (2001) warns that the economic and social transformation and the improvement of the welfare of the poorest regions were understood as a natural result of the agricultural modernization process, and consequently an alleged association with the increase of family income and "rural development". The author reports that since the 1980s, some public policies withdrew rural development of the discussions, returning to be addressed in the 1990s.

Schneider (2010) highlights four key factors that contributed to the change in the understanding of rural development in Brazil in the mid-1990s. The first factor is related to the recognition of family farming as a social category. The second factor refers to the growing State 
influence and action in rural areas both through public policies and actions related to food security, land reform, among others. The third factor concerns the changes in the political and ideological context, as the sectors of agrarian elites have been forced to modify their thoughts on social policies and so, an argument aimed at unveiling the differences between farmers has been constructed. Finally, the author highlights the fourth factor as the relationship of rural development with environmental sustainability.

Considering the above, there has been a change of focus in the understanding of rural development as an alternative model to the paradigm of "conservative modernization." Thus, studies on rural development have come to understand it as a phenomenon of multi-sectoral, multifunctional and multidimensional nature involving multi-actors (WILSON, 2007). Also worthy of mention are the studies that address the importance of family farming for the development of the rural environment, due to its importance in the generation of occupations and income (SANGALLI; SCHLINDWEIN, 2013), directing state actions, especially policies public, and the development and strengthening of this social category (GRISA; SCHNEIDER, 2015).

In this venue we aimed to prove that in Brazil different production systems coexist side by side and we believe that there is no way to develop a country without address this issue. That is what makes this work so unique. To shed lights in the new organizational arrangements and to undercover the bonds linking the small farm family to the land are in any case still a great challenge and might contribute to different strategies to push to rural development, especially on the role that public sector and local stakeholders could play in present time. In this scenario, taking into account the above characteristics of rural development, this study aims to examine rural in the state of Minas Gerais and verify that family farming is a key factor in explaining the level of rural development of Minas Gerais municipalities.

\section{DETERMINANT FACTORS OF RURAL DEVELOPMENT AND STRENGTHENING OF FAMILY FARMING}

In this research, it is necessary to discuss concepts that support rural development. Rural development processes are the overall outcome of the creation, unfolding, intertwining and mutual strengthening of rural development practices. This outcome is not a matter of simple and straightforward addition. In the current situation, rural development is far from the only transitional process (PLOEG; YINGZHONG; SCHNEIDER, 2010). Rural development processes as transitional processes meanings they are multi-level, multi-dimensional and multi-actor and they imply an extended time horizon (WILSON, 2007).

Ellis and Biggs (2001, p. 443) conceptualize rural development as "a set of practices and actions that seek to reduce poverty in rural areas in order to stimulate a process of participation that empowers rural people, allowing them to be able to control and set their priorities to effect changes". Rural development processes and policies emerge from specific and highly different backgrounds. They often reflect different and contrasting objectives, situations and dynamics (PLOEG; YINGZHONG; SCHNEIDER, 2010).

The literature about rural development emphasize the different dimensions which must be considered in this phenomenon analysis. Conterato, Schneider and Waquil (2007) shows that rural development is a multidimensional process, including aspects related to economic, social, demographic, institutional, political and environmental dimensions. Therefore, it is important to 
contemplate elements associated with these multiple dimensions to characterize the determinant factors of rural development.

Jorge and Moreira (1995) report that the development indicators should be listed in three major groups: i) vital, which include aspects linked to average life expectancy, age structure, child mortality, morbidity, and population growth rate; ii) economic, which are divided into structural (labor force, structure of production, capital, natural resources and structure of income distribution) and availability of goods and services (per capita income, consumer goods, basic services, social services); and iii) social, corresponding to issues related to class stratification, social mobility, representation in the political system, social participation and ownership concentration system.

In accordance with Buainain and Souza Filho (2006), the success of agriculture is not conditioned only by factors controlled from "gate inside." The conditions of the different segments of the production chain in which the agricultural holding is located, as well as the institutions and organizations that provide support, the science and technology infrastructure, the physical infrastructure, the human resources development to support public programs and the basic education services are extremely important in order to generate positive externalities for farmers.

Graziano da Silva (2002) reveals that poverty is an obstacle to development processes for two basic reasons: first, because it drains substantial part of the local resources used for daily consumer goods that have little inducing effect for the formation of virtuous circuits that generate employment and income; second, because it limits the size of local markets due to low per capita level of the majority population.

The generation of occupations is also an element in rural development processes. Veiga (2000) reports that development tends to separate the emergence of new jobs of the degree of regional urbanization, taking the example of farm units in which the household is small craft, commercial or industrial companies that are largely responsible for the diversification of regional economies.

Graziano da Silva (2002) shows how the rural environment can also offer non-agricultural occupations, such as tourism, recreation and a combination of jobs in small and medium sized companies, in the local-regional space. Thus, the creation of non-agricultural jobs in rural areas is considered by the author as a rural development strategy that involves new occupations (not necessarily jobs) that provide higher levels of income and new ways of retaining the population in rural areas.

Public investment also plays an important role in order to create conditions for the development of municipalities. A study conducted by the Instituto de Pesquisa Econômica Aplicada (IPEA, 2011) details how government social spending in health and education increases Gross Domestic Product (GDP) and household income. It was found that, when $\mathrm{R} \$ 1.00$ is spent on public education, GDP and income increase $R \$ 1.85$ and $R \$ 1.67$, respectively. Each $R \$ 1.00$ spent in health represents an increase of $\mathrm{R} \$ 1.70$ in GDP and $R \$ 1.44$ in family income.

With regard to spending in the agribusiness sector, a World Bank study (2006) shows that the improvement of public expenditure management has a positive impact on agriculture. It is emphasized that the expenses of the farming and livestock sectors should be based on a clearly defined strategy with priorities, a set of programs and policies that respond to these priorities; and the allocation of financial and human resources should be consistent with the strategies, policies and programs. 
According to Veiga (2000), many factors contribute to the rural development process such as: increased access to education and land in order to raise incomes and reduce poverty; diversification of agriculture and a multi-faceted rural environment; greater concentration of activities, due to the proximity advantages; and a set of well grounded institutions, allowing an appreciation of the territory.

Demographic and environmental factors also have an important relationship with the rural environment. Kageyama (2004) states that the higher the population density, the lower the isolation of rural areas and greater the opportunities for establishment of social networks, and, the higher the rural population and its growth, the greater the capacity of rural areas to retain population. Abramovay (2000) addresses that, as the notion of rurality incorporates nature as a value to be preserved - and not an obstacle that agricultural progress must inevitably remove- the policies and production practices targeted for sustainable exploration of biodiversity are strengthened.

In addition to the aspects that substantiate the choice of variables, it is also relevant to highlight how the different dimensions of rural development are characterized. In the study conducted by Conterato, Schneider and Waquil (2007), the social dimension used variables directly or indirectly related to the well-being and the individuals quality of life. The demographic dimension sought to characterize both general demographic aspects and certain specific aspects of the populations. In addition, the political and institutional dimension sought to characterize political participation and institutional environment. The economic dimension purpose was to establish indicators that would demonstrate the diversity of existing economic relations in relation to individuals or regional economies as a whole. The environmental dimension was chosen broadly to characterize the more general conditions of natural resources uses and their implications for the population and economic activities, as well as their reflections for the development.

Taking into account the importance of family farming and the recognition of its potential to arouse local economies in the context of rural development studies (SCHNEIDER, 2010), this work seeks to analyze whether family farming is a major factor in explaining the level of rural development. Therefore, it is relevant to understand the meaning of family farming. The Food and Agriculture Organization of the United Nations (FAO) defined family farming as:

A means of organizing agricultural, forestry, fisheries, pastoral and aquaculture production which is managed AND operated by a family and predominantly reliant on family labor, including both women's and men's. The family and the farm are linked, co-evolve and combine economic, environmental, social and cultural functions. (FAO, 2013, p. 2).

Regarding the aspects related to the strengthening of family agriculture, Sousa et al. (2015) report that the use of technology in the land factor, the production value, the degree of integration with the market and the intellectual dimension of farmers play an important role in the competitiveness of this social category. Buainain and Souza Filho (2006) also highlights some ways to strengthen family agriculture, such as the addition of value to their products; public policy instruments that enable the sustained competitiveness of enterprises; technical assistance and rural extension; the management of rural property and the management of forms of organization.

In Brazilian regions, Sangalli and Schlindwein (2013) emphasize the importance of knowing the indicators involving family agriculture for planning rural development programs that meet the specific characteristics. The authors point out that, even with more modest productivity rates, family farming contributes to the Brazilian agribusiness, especially the number of occupations and the generation of income to a large number of families who depend on land for their survival. 
From the foregoing, it is important to understand the rural development not only as a phenomenon closely related to economic growth, but that includes factors of different dimensions that influence this development. This research aimed to determine whether family agriculture can be an important factor in explaining the level of rural development in the municipalities of Minas Gerais, and, to do so, it is also important to highlight the conditioning factors for the strengthening and competitiveness of this social category.

\section{METHODOLOGICAL PROCEDURES}

The methodological approach of this study is presented in this section. The analytical sample is the state of Minas Gerais, and the analysis units are its 853 municipalities. In this study, severe outliers (values greater than or equal to 3 interquartile range down the first quartile or above the third quartile) were excluded from analysis. Thus, 26 municipalities were removed totaling 827.

For the operationalization of the methodological procedures of quantitative nature, a secondary database was composed from the following sources: Atlas do Desenvolvimento Humano no Brasil; Departamento de Informática do SUS (DATASUS); Data Social; Instituto Brasileiro de Geografia e Estatística (IBGE); Instituto de Pesquisa Econômica Aplicada (IPEA); Índice Mineiro de Responsabilidade Social (IMRS). The Software Statistical Package for Social Sciences (SPSS) was used for statistical processing of data that refer to a cross-section for the 2010 period.

The factor analysis technique was used for the extraction of the determinants of rural development for the municipalities of Minas Gerais. To this end, sixteen variables that have a positive theoretical expectation for rural development were selected. Table 1 shows the variables and the theoretical background, based on the elements presented in the literature review.

The variables used in this research corroborates the characteristics of the dimensions of rural development mentioned in Conterato, Schneider and Waquil (2007). For example, in accordance with the variables employed by the authors, the elements are related to the values of different economic sectors, not only the rural sector. Other factors such as the characteristics of households in the social dimension; the participation in the institutional and political dimension; and the environmental preservation in the environmental dimension were considered.

Table 1 - Variables used in the factor analysis and theoretical background

\begin{tabular}{|c|c|c|}
\hline Dimension & Variables & Theoretical Background \\
\hline \multirow{5}{*}{ Economic } & Per capita spending on agriculture (\%) & Word Bank (2006) \\
\hline & Per capita spending on education (\%) & IPEA (2011) \\
\hline & Per capita spending on infrastructure (\%) & Buainain and Souza Filho (2006) \\
\hline & Per capita spending on health (\%) & IPEA (2011) \\
\hline & Farming and livestock's contribution to Value Added (\%) & Word Bank \\
\hline \multirow{4}{*}{ Social } & Households with treated water (\%) & Jorge and Moreira (1995) \\
\hline & Households with collected waste (\%) & Jorge and Moreira (1995) \\
\hline & Households with sewage treatment (\%) & Jorge and Moreira (1995) \\
\hline & Households with electricity (\%) & Buainain and Souza Filho (2006) \\
\hline \multirow{3}{*}{$\begin{array}{c}\text { Political- } \\
\text { institutional }\end{array}$} & Enrollment rate in elementary school (\%) & Veiga (2000) \\
\hline & Enrollment rate in high school (\%) & Veiga (2000) \\
\hline & Attendance in the first round of elections (\%) & Jorge and Moreira (1995) \\
\hline \multirow{2}{*}{ Demographic } & Rural households out of extreme poverty (\%) & Graziano da Silva (2002) \\
\hline & Employed personnel the farming and livestock sector (\%) & Graziano da Silva (2002) \\
\hline
\end{tabular}




\begin{tabular}{c|l|c}
\hline Dimension & \multicolumn{1}{|c|}{ Variables } & Theoretical Background \\
\hline \multirow{2}{*}{ Environmental } & Atlantic Rainforest area (\%) & Abramovay (2000) \\
& Sustainable use area (\%) & Abramovay (2000) \\
\hline
\end{tabular}

Source: Authors.

The method of principal components was used for the extraction of the factors and the Kaiser-Meyer-Olkin (KMO) measure was used to extract the number of factors required to describe the data in which explained variance is greater than one (PESTANA; GAGEIRO, 2008). Also, in order to assess the adequacy of the data, the Bartlett test was applied and test needs to be statistically significant, i.e., $p<0.05$. The Varimax orthogonal method was used for the rotation of the main components (HAIR et al., 2009).

According to Kageyama (2004), the (economic, social, cultural, political) development is a complex concept and can only be defined through simplification, including "decomposition" of some of its aspects and "approach" by some forms of measures. In this paper, rural development is measured through the Rural Development Index (RDI), calculated based on the scores obtained in the factor analysis:

$$
F_{i j}=\left(\frac{F-F_{\min }}{F_{\max }-F_{\min }}\right)
$$

Where: $\mathrm{F}_{\min }$ and $\mathrm{F}_{\max }$ are the minimum and maximum values observed for the $j$-th factor score of the $i$-th Minas Gerais municipality. In the construction of the Rural Development Partial Index of the $i$-th municipality, the following equation was defined:

$$
I D R_{i}=\frac{\sum_{i}^{j}\left(w_{i} F_{i}\right)}{\sum_{i}^{j} w_{i}}
$$

Where: IDR is the partial index of the $i$-th municipality, $F_{i}$ represents the factor scores and $W_{i}$ refers to the proportion of explained variance to each factor. For the construction of the Rural Development Index (RDI), 100 was considered, by interpolation, the greatest value and, thus, it is attributed to municipalities a hierarchy.

According to Pestana and Gageiro (2008), considering the multinomial logit model with a nominal dependent variable with three classes, the dependent variable $Y$ can assune the value of any of the three classes. However, it is necessary to standardize the system for a category of the dependent variable, and one of the coefficients related to one of the classes must be set equal to 0 . Thus, taking $B_{0}=0$, the chances of occurring each of the classes of the dependent variable related to the reference classes 0 are:

$$
\begin{aligned}
& \operatorname{Ln}\left[\frac{P(Y=1) \mid X)}{P(Y=0) \mid X)}\right]=X \beta_{1} \\
& \operatorname{Ln}\left[\frac{P(Y=2) \mid X)}{P(Y=0) \mid X)}\right]=X \beta_{2}
\end{aligned}
$$

The multinomial logit model was used in the analysis of rural development and its relation to family farming with reference to the variables shown in Table 2. 
Table $\mathbf{2}$ - Variables used in the multinomial logit model and theoretical background

\begin{tabular}{l|c}
\hline \multicolumn{1}{c|}{ Variables } & Theoretical Background \\
\hline $\begin{array}{l}\text { Employed in family farming } \\
\text { Family farmers with high school education }\end{array}$ & \\
$\begin{array}{l}\text { Family farming establishments with production } \\
\text { Family farming establishments with tractors } \\
\text { Family farming establishments that contracted rural credit } \\
\text { Family farming establishments that received technical assistance }\end{array}$ & $\begin{array}{c}\text { Buainain and Souza Filho (2006); } \\
\text { Sangalli and Schlindwein (2013); } \\
\text { Sousa et al. (2015) }\end{array}$ \\
\hline
\end{tabular}

Source: Authors.

In this work, the mentioned indicators were used in order to investigate the relationship between the explanatory variables related to family farming and a categorical variable representing the degree of rural development of the Minas Gerais municipalities, calculated through RDI.

\section{RESULTS AND DISCUSSION}

In this section, the results of the study are presented, interpreted in the light of the theoretical background.

\subsection{Rural development in the state of Minas Gerais}

Factor analysis revealed that the variables presented good adjustment, according to the KMO test with coefficient of 0.686 , and statistical consistency, confirmed by the Bartlett's sphericity test, significant at the $1 \%$ level of probability. After the rotation of the main components, the Varimax orthogonal method was used, retaining the factors that exhibit higher factor loadings for the summarization of the 16 variables that characterize different dimensions of the rural development. These variables were compiled into six factors taking into account the characteristic root (eigenvalue) greater than one. It is noted by Table 3 that the extracted factors explain, together, $67.41 \%$ of the total data variance. Table 4 shows the factor loadings and the commonalities of the retained factors.

Table 3 - Characterization of the extracted factors

\begin{tabular}{c|c|c|c}
\hline Factor & Characteristic Root & Variance Explained by the Factor (\%) & Accumulated Variance (\%) \\
\hline 1 & 2,77 & 17,35 & 17,35 \\
2 & 2,34 & 14,65 & 32,00 \\
3 & 1,66 & 10,36 & 42,36 \\
4 & 1,37 & 8,56 & 50,92 \\
5 & 1,32 & 8,26 & 59,18 \\
6 & 1,31 & 8,23 & 67,41 \\
\hline
\end{tabular}

Source: Authors. Research results. 
Table 4 - Matrix of the determinant factors of rural development

\begin{tabular}{l|c|c|c|c|c|c}
\hline Variables/Factor & $\mathbf{1}$ & $\mathbf{2}$ & $\mathbf{3}$ & $\mathbf{4}$ & $\mathbf{5}$ & $\mathbf{6}$ \\
\hline Households with collected waste (\%) & 0,927 & & & & & \\
Households with treated water (\%) & 0,862 & & & & & \\
Households with sewage treatment (\%) & 0,825 & & & & & \\
Households with electricity (\%) & 0,651 & & & & & \\
Per capita spending on education (\%) & & 0,835 & & & & \\
Per capita spending on health(\%) & & 0,829 & & & & \\
Per capita spending on infrastructure (\%) & & 0,539 & & & & \\
Per capita spending on agriculture (\%) & & & 0,859 & & & \\
Enrollment rate in high school (\%) & & & 0,852 & & & \\
Enrollment rate in elementary school (\%) & & & & 0,796 & & \\
Sustainable use area (\%) & & & & & 0,793 & \\
Atlantic Rainforest area (\%) & & & & 0,759 & \\
Rural households out of extreme poverty (\%) & & & & 0,841 \\
Attendance in the first round of elections (\%) & & & & \\
Employed personnel in the farming and livestock sector (\%) & & & & & \\
Farming and livestock's contribution to Value Added (\%) & & & & & \\
\hline
\end{tabular}

Source: Authors. Research results.

The six retained factors were named: social aspects, sectoral public investment, institutional aspects, environmental aspects, political and demographic aspects and conditions of farming and livestock activities. The factors are described below:

Factor 1 - Social aspects: This factor has the greatest variance, corresponding to $17.35 \%$ of the total variance. That is, the factor that most contributed to the promotion of rural development in this study. The variables that compose it are associated with quality of life and people's wellbeing, since they are related to basic sanitation (waste collection, water and sewage treatment) and access to electricity, which, as Buainain and Souza Flho (2006) report, is a key infrastructure condition for the success of agricultural activities. Melo and Parré (2007) and Matosinhos, Ferreira and Campos (2017) also highlighted in what way electricity is an important factor associated with the structure required for production in rural areas.

Factor 2 - Sectoral Public Investment: This factor is associated with the way in which public investment is directed to different sectors, such as education, health, infrastructure, farming and livestock. It is worth noting that public spending in different sectors affect the improvements of the municipalities' development, because, as demonstrated by an IPEA research (2011), public expenditure in different areas increases both GDP and the income of the population.

Factor 3 - Institutional Aspects: This factor is linked to the institutional aspects related to education access. As evidenced by Veiga (2000), access to education is an essential element in improving income and reducing poverty, which is an important aspect for the promotion of rural development.

Factor 4 - Environmental Aspects: It is associated with the preservation of the environment. Navarro (2001) reports how sustainable rural development, which is related to actions guided from the perspective of environmental standards, has gained ground in the agendas of discussions on the studies covering rural environment. At this juncture, preserving nature becomes a key issue for the development of rural activities, for the protection requirements to the environment are increasingly strict. 
Factor 5 - Political and Demographic Aspects: The variable attendance in the first round of elections is the number of voters who attend this turn in relation to the total number of registered voters (a proxy for political participation), representing the political aspect of this factor. Graziano da Silva (2002) reveals how poverty is an obstacle to development processes. Therefore, the greater the number of people living in rural areas and are out of extreme poverty, the better tends to be the rural development level of the municipality.

Factor 6 - Conditions of Farming and Livestock activities: It portrays the conditions of farming and livestock activities of the municipalities. The variable employed personnel in the farming and livestock sector represents how the creation of occupations is important for rural development in order to attract and retain population (GRAZIANO DA SILVA, 2002) and boost local economies (VEIGA, 2000). The farming and livestock's contribution to Value Added is an indicator that measures the economic performance of the sector. Melo and Parré (2007) also found a determinant factor of rural development related to the structure and economic performance of the agricultural sector, adding variables related to labor productivity in agriculture and municipal agricultural income.

The set of extracted factors represents aspects related to rural development that determine competitive advantages to municipalities. The process of rural development also contributed to the improvement of the indicators used in this study to the composition of the strategic factors. Upon completion of the factor analysis, it was calculated the Rural Development Index (RDI) for the Minas Gerais municipalities based on factor scores and characteristic root values.

Reparametrized the index, it was found that the minimum value found was 35.37 and refers to the municipality of Japonvar, located in the North of Minas Gerais. Maripá de Minas, however, located in the region of Zona da Mata, presented the greatest RDI. When comparing the RDI of these municipalities with the Municipal Human Development Index (MHDI), calculated by the United Nations Development Programme (UNDP), it can be observed that, according to the classification criteria of the UNDP, Japonvar and Maripá de Minas presented average (0.618) and high (0.749) MHDI. This shows that, for the municipality of Japonvar, human development conditions (which involves the longevity, education and income dimensions) are better when compared to the level of rural development. The Maripá de Minas municipality presented good results for both indicators, confirming its development character.

In order to classify municipalities into groups, it was considered 0.5 standard deviation from the mean. The municipalities considered with high degree of development were the ones that had results higher or equal to the mean plus 0.5 standard deviation. Municipalities that presented results between 0.5 standard deviation above and 0.5 standard deviations below mean were grouped as municipalities with average development. For municipalities with average development, is grouped with those results. The municipalities with low development were the ones that had results lower or equal to the mean minus 0.5 standard deviation. Figure 1 shows how the municipalities of different groups are distributed in the territory of the state of Minas Gerais, according to their RDIs. 


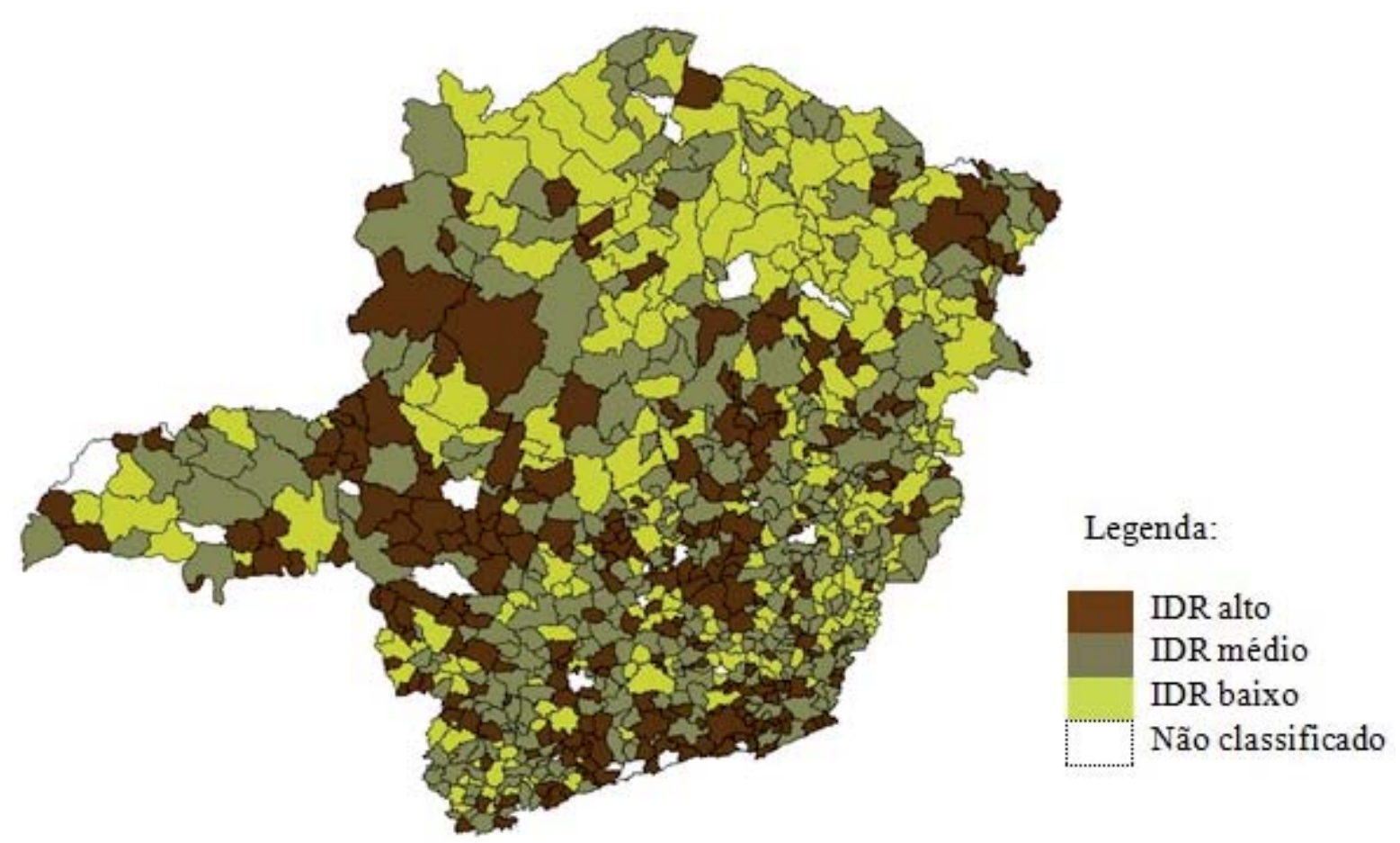

Figure 1 - Minas Gerais state area divided based on municipalities' RDI Source: Authors. Research results.

It is possible to observe the disparities between the municipalities of Minas Gerais on the map. It is noted that the largest number of municipalities with low rural development is concentrated in the north, Vale do Jequitinhonha and Vale do Mucuri regions. On average, the municipalities of these regions presented the RDI (56.60; 61.06; 61.75; respectively) lower than the state average (63.65), which emphasizes their low development. These results are similar to the findings of Moura et al. (2013), which calculated a Rural Development Index (RDI) for Minas Gerais and an index of the demographic, social, economic and environmental dimensions. The authors reported that the municipality with the lower IDR and lower rate of the economic dimension is located in the northern region of the state and the municipality with the lowest rate of the environmental dimension is in the Vale do Mucuri.

The RDI values for low-income municipalities coincide with the Human Development Index (HDI), which is available in the Human Development Atlas in Brazil. The HDI of the North (0.62), the Jequitinhonha Valley (0.49) and the Mucuri Valley (0.60) are lower than the state average (0.67). The HDI shows that the situation is even more critical in the Jequitinhonha Valley. Silva and Filho (2009) explained it by pointing out the reasons, which are the adverse climatic conditions, the poor condition of soil and the low productivity of agricultural crops. These factors make the survival difficult, especially in rural areas where a large part of the population lives.

It was also found that most of the municipalities with high rural development is located in the Triângulo Mineiro and Alto Paranaíba, Metropolitan and Zona da Mata regions. The other regions of Minas Gerais had a higher number of municipalities classified with medium development. These results corroborate the study by Moura et al. (2013), which found that the Minas Gerais municipality with the highest rural index for the economic dimension is located in the Zona da Mata region. As well as in regions with low rural development, IDR values also resemble the 
HDI for regions with high development. The HDI of Triângulo Mineiro and Alto Paranaíba (0.71), Zona da Mata (0.67) and Metropolitan (0.69) are higher than average. In Zona da Mata region it is equal the state average (0.67). The study by Bittencourt and Lima (2014) on the profile of rural development of the Triangle and Alto Paranaiba regions highlights the characteristics of these locations. The high rates of job creation, the land quality, the strategic location for the production flow and the major investments in agribusiness that some municipalities have received are potentialities of these regions in terms of rural area development. Therefore, this research also states the high rural development noticed in this region.

The results of this research reveal the importance of deepening the analysis of rural development in regional contexts, as done in some studies, which showed how high and low levels of development are concentrated in specific regions (MELO; PARRÉ, 2007; CONTERATO; SCHNEIDER; WAQUIL, 2007; MOURA et al., 2013; BITTENCOURT; LIMA, 2014; MATOSINHOS; FERREIRA; CAMPOS, 2017). This shows that some constraints present in the regions of the state of Minas Gerais, such as the IDHM, can explain what leads these localities to perform differently in the IDR. In addition, although the IDR shows a panorama of how the state of Minas Gerais is divided in relation to the level of rural development and how this division reveals differences of performance, it is worth mentioning that, according to Conterato, Schneider and Waquil ( 2007), the state of rural development of a region is also the result of historical processes of social changes.

\subsection{Family agriculture and rural development in Minas Gerais}

The RDI calculation allowed rank the Minas Gerais municipalities regarding the level of rural development. Thus, the nominal dependent variable (y) was grouped into 3 categories to perform the multinomial logit model and the municipalities with high rural development (y $=0$ ) were used as reference category. The proportional distribution of the model most of the municipalities are part of the medium category (333), followed by the high (259) and low (235) rural development categories.

The model was significant at $1 \%$, which indicates that at least one independent variable has considerable power to explain the phenomenon in question and all variables were significant less than $5 \%$ probability. Table 5 shows the variables used in the statistical model and their respective coefficients and significances, as well as the odds ratio, considering the three groups of municipalities. The reference to groups 1 and 2 (medium and low rural development) were the municipalities classified with high level of rural development. That is, the table shows the classification only for these two groups, since the group of high development was selected as the reference category. 
Table 5 - Rural Development prediction model

\begin{tabular}{c|l|c|c|c}
\hline Group 1 & Variables & Estimated Coefficient & Significance & Exp Odds ratio \\
\hline & AFENSMED & 0,009 & 0,698 & 1,009 \\
& ESTAFCR & 0,023 & 0,145 & 1,024 \\
Average Rural & ESTAFPROD & 0,013 & 0,191 & 1,013 \\
Development & ESTAFTRAT & 0,015 & 0,010 & 1,015 \\
& OCUPAF & $-0,001$ & 0,005 & 0,999 \\
& ESTATEC & $-0,003$ & 0,003 & 0,997 \\
\hline Group 2 & Variables & Estimated Coefficient & Significance & Exp Odds ratio \\
\hline \multirow{4}{*}{ Low Rural } & AFESMED & 0,083 & 0,005 & 1,083 \\
Development & ESTAFCR & 0,049 & 0,002 & 1,050 \\
& ESTAFPROD & 0,030 & 0,010 & 1,030 \\
& ESTATRAT & 0,010 & 0,092 & 1,010 \\
& OCUPAF & $-0,001$ & 0,100 & 0,999 \\
& ESTATEC & $-0,005$ & 0,000 & 0,995 \\
\hline
\end{tabular}

Source: Authors. Research results.

The coefficients of the independent variables (AFENSMED, ESTAFCR and ESTAFPROD) were not significant when comparing the group of municipalities with medium development in relation to the ones with high rural development group, which means that the impact of these variables for this group is null. The remaining variables were significant at $5 \%$ for this group. When the group of municipalities with low rural development was compared with the high rural development group, all variables were significant at 5\% (AFENSMED, ESTAFCR, ESTAPROD and ESTAFATEC) and at 10\% (OCUPAF and ESTAFTRAT).

Values greater than one for the odds ratio increase the probability of rating the municipalities in the high rural development group, while values lower than one decrease such probability. Therefore, the variables AFENSMED, ESTAFCR, ESTAPROD and ESTAFTRAT increase the likelihood of the municipalities of the low rural development group to be included in the high rural development group, as well as the variable ESTAFTRAT increase this probability to the municipalities of the medium rural development group. The variables OCUPAF and ESTAFATEC, however, reduce this probability for both groups.

As in a regression model, each coefficient must be interpreted as an estimate of the effect that an independent variable produces on the dependent variable, keeping constant the others. In the multinomial logit model, the regression is expressed in terms of the natural logarithm of the odds ratio. So, there are the following regressions:

Group 1: -0,314 + 0,015ESTAFTRAT - 0,0010CUPAF - 0,003ESTAFATEC

Group 2: $-1,698+0,083$ AFENSMED + 0,049ESTAFCR + 0,030ESTAPROD + 0,010ESTAFTRAT $-0,0010$ CUPAF - 0,005ESTAFATEC

Thus, for municipalities classified in the medium rural development group (group 1), when increasing by 1 unit the number of establishments in the family farmer with tractor, there is an increase of 0,015 in the logarithm of the odds ratio of belonging to the high rural development group. In contrast, an increase of 1 unit in the number of employed people in family farming and in family farming establishments that received technical assistance, there is a decrease of 0.001 and 0.003 in the logarithm of the odds ratio of having a high level of rural development.

For municipalities classified with a low level of rural development (group 2), when increasing by 1 unit the number of family farmers with high school education, family agriculture 
establishments that contracted rural credit, family agricultural establishments with production and with tractor, there is an increase of $0.083 ; 0.049 ; 0.030 ; 0,010$, respectively, in the logarithm of the odds ratio of belonging to high rural development group. On the other hand, a 1-unit increase in the number of employed people in family farming and in family farming establishments that received technical assistance, there is a decrease of 0.001 and 0.005 in the logarithm of the odds ratio of having a high level of development rural.

The literature shows that all these aspects (rural credit, technical assistance and rural extension (BUAINAIN; SOUZA FILHO, 2006), productivity (SANGALLI; SCHLINDWEIN, 2013), mechanization and formal instruction (SOUSA et al., 2015) are contributions that indicate the strengthening of family farming and are favorable to rural development processes. Sousa et al. (2015) revealed a low competitiveness of family agriculture associated with aspects such as the low frequency of the use of technical assistance and low machines and equipment. However, in this study, for the two regressions, the variables OCUPAF and ESTAFATEC showed an unexpected signal varying inversely with the level of rural development. The other variables in both cases showed a positive relationship with rural development, which was expected.

A possible explanation for the negative sign of the variable OCUPAF may be related to productivity. Since all variables were relativized by the number of family farming establishments, this means that in municipalities with the highest number of employed people in family farming per establishment there may be a lower productivity of work. However, it is important to highlight that the family farming establishments reveals a diversification of agricultural products in comparison to commodities systems, where the productivity is measured in large-scale. Therefore, the great deal about family farming should not be measure only buy the productivity.

For the variable ESTAFATEC, which is the number of establishments that receive technical assistance in relation to the total of family farming establishments, it was considered the technical assistance of federal, state and local government agencies. It is assumed that in municipalities where rural areas are more developed and farmers are organized in associations or cooperatives, these organizations provide technical guidance to farmers on their properties. In addition, many farmers also use the support of private companies or hired professionals. Therefore, these elements are possible explanations for the unexpected behavior of this variable.

Table 6 shows the success rate for each category and the overall performance of the model. The highest percentage of correct answers for ratings was for the category of medium rural development. The total percentage of cases classified correctly is $45.6 \%$. It is noteworthy that the predictor variables used in the model correspond to important aspects for the analysis of the relationship between family agriculture and rural development, as they are mechanisms related to the strengthening and competitiveness of this social category.

Table 6 - Performance of the multinomial logit model Predicted

\begin{tabular}{c|c|c|c|c}
\hline \multirow{2}{*}{ Observed } & \multicolumn{4}{|c}{ Predicted } \\
\cline { 2 - 5 } & $\mathbf{0}$ & $\mathbf{1}$ & $\mathbf{2}$ & Correct percentage \\
\hline 0 & 59 & 158 & 33 & $23,6 \%$ \\
1 & 48 & 236 & 51 & $70,4 \%$ \\
2 & 28 & 130 & 80 & $33,6 \%$ \\
\hline Overall percentage & $16,4 \%$ & $63,7 \%$ & $19,9 \%$ & $45,6 \%$ \\
\hline
\end{tabular}

Source: Authors. Research results. 
Given that the guiding conception of rural development used in this study takes as reference a new model that seeks, among other things, to enhance the economies of scope rather than the economies of scale and the pluriactivity of rural households, this work seems to confirm the importance of encouraging initiatives that contribute to the link between strengthening family agriculture and promoting rural development, through sectorial public policies.

\section{FINAL CONSIDERATIONS}

The change in focus of agricultural modernization model for the approach of rural development in Brazil brought up the need to consider rural development as a phenomenon of multi-sectoral and multidimensional nature that involves various actors, considering the dynamics that goes in rural environment beyond the agricultural and farming systems. In addition, it is emphasized the importance of a development model capable of ensuring the food supply of the population, but at the same time able to generate income and contribute to the eradication of poverty in rural areas.

Through the proposed analysis, it became possible to know the determinant factors of rural development of Minas Gerais municipalities, which were defined as: social aspects, sectoral public investment, institutional aspects, environmental aspects, political and demographic aspects and conditions of farming and livestock activities. The RDI results show that most of the municipalities falls within the category of medium rural development followed by the categories high and low development. Much of municipalities with high rural development is located in the Alto Paranaíba, Zona da Mata and Metropolitan regions and the largest number of municipalities with low rural development is concentrated in the regions of Vale do Jequitinhonha and Vale do Mucuri. The municipalities of the average rural development group are widespread throughout Minas Gerais territory.

The multinomial logit model was used to verify if family farming can be an important factor to explain the rural development level of Minas Gerais municipalities. With the group of municipalities with high rural development as reference category, it was found that the model showed $45.6 \%$ of cases classified correctly, i.e., for that percentage of municipalities, family farming is able to explain the level of rural development. It is noteworthy that the search for the predictor variables was one of the limitations of this study, given the low degree of updating of the official databases that include variables related to family farming.

The results obtained through this study emphasizes the need for guidance from State actions (efficient allocation of public resources and the development of public policies, for example) aimed at promoting the development of the regions with the highest number of municipalities that had low rural development. Indeed, knowing these differences between the municipalities contributed to the targeting of state actions to locations with lower levels of development, which constitutes a useful tool for decision makers and the development of public policies that deal with the crucial points that should be addressed in a rural development model. 


\section{REFERENCES}

ABRAMOVAY, R. Funções e medidas da ruralidade no desenvolvimento contemporâneo. Texto para discussão n. 702. Rio de Janeiro: IPEA, 2000.

BUAINAIN, A. M.; SOUZA FILHO, H. M de. Agricultura familiar, agroecologia e desenvolvimento sustentável: questões para debate. 1. ed. Brasília: Instituto Interamericano de Cooperação para a Agricultura (IICA), 2006. (Série Desenvolvimento Rural Sustentável, v. 5).

BITTENCOURT, G. M.; LIMA, J. E. Perfil do Desenvolvimento Rural dos Municípios da Mesorregião do Triângulo Mineiro e Alto Paranaíba. Gestão \& Regionalidade, São Caetano do Sul, SP, v. 30, n. 89, p. 4-19, maio/ago. 2014.

CONTERATO, M. A.; SCHNEIDER, S.; WAQUIL, P. D. Desenvolvimento rural no Estado do Rio Grande do Sul: uma análise multidimensional de suas desigualdades regionais. Redes, Santa Cruz do Sul, RS, v. 12, n. 2, p. 163-95, maio/ago. 2007.

DELGADO, G. Expansão e modernização do setor agropecuário no pós-guerra: um estudo da reflexão agrária. Estudos Avançados, São Paulo, v. 15, n. 43, p. 157-72, set./dez. 2001.

ELLIS, F.; BIGGS, S. Evolving themes in rural development 1950s-2000s. Development Policy Review, v. 19, n. 4, p. 437-48, dez. 2001.

FOOD AND AGRICULTURE ORGANIZATION OF THE UNITED NATIONS (FAO). Retrieved from International Year of Family. Master Plan, 2013.

GRAZIANO DA SILVA, J. F. Velhos e novos mitos do rural brasileiro: implicações para as políticas públicas. In: ARBIX, G.; COMIN, A.; ZILBOVICIUS, M.; ABRAMOVAY, R. (Org.). Brasil, México, África do Sul, Índia e China - diálogo entre os que chegaram depois. São Paulo: Editora UNESP, 2002. p. 151-74.

GRISA, C.; SCHNEIDER, S. Políticas públicas de desenvolvimento rural no Brasil. Porto Alegre: Editora da UFRGS, 2015.

HAIR, J. F.; BLACK, W. C.; BABIN, B. J.; ANDERSON, R. E; TATHAM, R. L. Multivariate Data Analysis. 7. th. Nova Jersey, EUA: Pearson Prentice Hall, 2009.

INSTITUTO DE POLÍTICA ECONÔMICA APLICADA (IPEA). Gastos com a política social: alavanca para o crescimento com distribuição de renda. Comunicados do IPEA, n. 75, 2011.

JORGE, F. T.; MOREIRA, J. O. C. Economia. São Paulo: Atlas, 1995.

KAGEYAMA, A. Desenvolvimento rural: conceito e medida. Cadernos de Ciência \& Tecnologia, Brasília, DF, v. 21, n. 3, p. 379-408, set./dez. 2004.

MATOSINHOS, L. A.; FERREIRA, M. A. M.; CAMPOS, A. P. T. de. Typifying the demand for rural electrification: an analysis in southeastern Brazil. International Journal of Energy Economics and Policy, v. 7, n. 5, p. $227-$ 34, 2017.

MELO, C. O.; PARRÉ, J. L. Índice de desenvolvimento rural dos municípios paranaenses: determinantes e hierarquização. Revista de Economia e Sociologia Rural, Brasília, v. 45, n. 2, p. 329-65, abr./jun. 2007.

MOURA, R. A.; FERREIRA NETO, A. J.; OLIVEIRA, P. C.; FERREIRA, M. A. M. Desempenho dos municípios de Minas Gerais (Brasil) nos Indicadores de Desenvolvimento Rural (IDR). Revista de Extensão e Estudos Rurais, Viçosa, MG, v. 2, n. 1, p. 119-51, 2013.

NAVARRO, Z. Desenvolvimento rural no Brasil: os limites do passado e os caminhos do futuro. Estudos Avançados, São Paulo, v. 15, n. 43, p. 83-100, set./dez. 2001.

PESTANA, M. H; GAGEIRO, J. N. Análise de dados para ciências sociais: a complementaridade do SPSS. 5. ed. Lisboa: Sílabo, 2008. 694p.

PLOEG, J. D. V. D.; YINGZHONG, Y.; SCHNEIDER, S. Rural development reconsidered: building on comparative perspectives from China, Brazil and the European Union. Rivista di Economia Agraria, v. LXV, n. 2, p. 16390, 2010. 
SANGALLI, A. R.; SCHLINDWEIN, M. M. A. Contribuição da agricultura familiar para o desenvolvimento rural de Mato Grosso do Sul-Brasil. Redes, Santa Cruz do Sul, RS, v. 18, n. 3, p. 82-99, set./dez. 2013.

SCHNEIDER, S. Situando o desenvolvimento rural no Brasil: o contexto e as questões em debate. Revista de Economia Política, São Paulo, v. 30, n. 3, p. 511-31, jul./set. 2010.

SILVA, S. P.; ALVES FILHO, E. Impactos econômicos do Pronaf em territórios rurais: um estudo para o Médio Jequitinhonha - MG. Revista Econômica do Nordeste, Fortaleza, CE, v. 40, n. 3, p. 481-98, jul./set. 2009.

SOUSA, E. P.; CORONEL, D. A.; BENDER FILHO, R.; AMORIM, A. L. Competitividade da agricultura familiar no Rio Grande do Sul. Reunir: Revista de Administração, Contabilidade e Sustentabilidade, Campina Grande, PB, v. 5, n.1, p. 106-23, 2015.

VEIGA, J. E. A face rural do desenvolvimento - natureza, território e agricultura. Porto Alegre: Editora da UFRS, 2000.

WILSON, G. A. Multifunctional agriculture: a transition theory perspective. Oxfordshire, UK: CAB International, 2007.

WORLD BANK. Moldova: agricultural policy notes policy priorities for agricultural development. Public Expenditures, v. 2, 2006.

\section{Sobre os autores:}

Luana Ferreira dos Santos: Doutoranda em Administração pela Universidade Federal do Rio Grande do Norte (UFRN). Mestra em Administração e Gestora do Agronegócio pela Universidade Federal de Viçosa (UFV). E-mail: luana_agronegocio@hotmail.com

Marco Aurélio Marques Ferreira: Doutor em Economia Aplicada pela Universidade Federal de Viçosa (UFV). Professor Associado da UFV. E-mail: marcoufv1@gmail.com

Ana Paula Teixeira de Campos: Doutora em Ciências Sociais em Desenvolvimento, Agricultura e Sociedade pela Universidade Federal Rural do Rio de Janeiro (CPDA/UFRRJ). Pós-doutoranda no Programa de Pós-Graduação em Administração na Universidade Federal de Viçosa (PPG-ADM/ UFV). E-mail: aptcampos@gmail.com 
